\title{
EFFECT OF MUNICIPAL SEWAGE SLUDGE ON SOIL CHEMICAL PROPERTIES AND CHEMICAL COMPOSITION OF SPRING WHEAT
}

\author{
WPŁYW KOMUNALNEGO OSADU ŚCIEKOWEGO NA WŁAŚCIWOŚCI \\ CHEMICZNE GLEBY I SKŁAD CHEMICZNY PSZENICY JAREJ
}

\begin{abstract}
Municipal sewage sludge from rural sewage treatment plants is characterized by a substantial content of organic matter and macronutrients, which can be used in cultivation of cereals. In a farm located in the commune of Iwanowice in the south of Poland (Malopolska province), municipal sewage sludge was applied under spring wheat cultivation. The experiment was set up on heavy soil with slightly acid reaction and medium content of available forms of $\mathrm{P}, \mathrm{K}, \mathrm{Mg}$. Application of sewage sludge in a dose of $23 \mathrm{Mg}$ fresh matter per hectare (4.21 Mg d.m.) led to no significant changes in chemical properties of the soil. Application of sewage sludge significantly increased yield of spring wheat. That increase led to a significant decrease in the content of $\mathrm{N}, \mathrm{P}, \mathrm{K}$, $\mathrm{Na}, \mathrm{Mg}$ and $\mathrm{Ca}$ in spring wheat. Utilization of $\mathrm{N}, \mathrm{Mg}, \mathrm{K}, \mathrm{P}$ and $\mathrm{Ca}$ from sewage sludge by spring wheat was at a level of $82,63,44,36,9 \%$, respectively, of the amount introduced with the waste. Application of municipal sewage sludge significantly decreased the value of $\mathrm{Ca}: \mathrm{P}$ ratio in spring wheat grain and straw. The sewage sludge did not cause a significant change in the values of $\mathrm{Ca}: \mathrm{Mg}, \mathrm{K}: \mathrm{Na}, \mathrm{K}:(\mathrm{Ca}+\mathrm{Mg}), \mathrm{K}: \mathrm{Mg}$ and $\mathrm{K}: \mathrm{Ca}$ ratios in spring wheat grain and straw. Municipal sewage sludge can be used environmentally, including for fertilization of cereals, provided that environmental standards are kept.
\end{abstract}

Keywords: spring wheat, municipal sewage sludge, macroelements, element ratio, element utilization

\section{Introduction}

Municipal sewage sludge should be treated as a raw material with a certain fertilizer or energy value. Environmental use of this waste is an ecologically and economically justified method of processing it $[1,2]$. This waste is a potential source of organic matter, nutrients, which are used in land reclamation for agricultural purposes [3, 4]. Organic waste, including sewage sludge, is also used in cultivation of energy crops [5, 6]. Application of

\footnotetext{
${ }^{1}$ Department of Agricultural and Environmental Chemistry, University of Agriculture in Krakow, al. A. Mickiewicza 21, 31-120 Kraków, Poland, phone +48 1266243 45, +48 12662 4348, fax +48 126624341 , email: jacek.antonkiewicz@urk.edu.pl

${ }^{2}$ Biological Sewage Treatment Plant, Chemical Emergency Unit in Tarnów, Grupa Azoty S.A., ul. E. Kwiatkowskiego 8, 33-101 Tarnów, Poland, phone +48 1463307 81, fax +48 $1463307 \quad 18$, email: kucyk123@poczta.onet.pl

${ }^{3}$ Institute of Plant Production, Department of Crop Production, University of Agriculture in Krakow, al. A. Mickiewicza 21, 31-120 Kraków, Poland, phone +48 1266243 85, email: rrwitkow@cyf-kr.edu.pl

*Corresponding author: monika.tabak@urk.edu.pl
} 
large doses of municipal sewage sludge, burdened with heavy metals, may cause chemical contamination of soils $[7,8]$. On soils contaminated with heavy metals coming from large doses of sewage sludge, it is recommended to use energy crops for phytoextraction of these contaminants [9]. Cereals can also be used for phytoextraction (phytoremediation) of chemical contaminants from organic waste, composts [10].

Owing to a high content of organic matter and a high calorific value, municipal sewage sludge can be intended to be used also for energy purposes [11, 12]. Municipal sewage sludge is also a potential source of macronutrients and microelements which can be used in production of composts intended to be used for fertilization of plants [7, 13, 14]. It is also permissible to use municipal sewage sludge in cultivation of cereals while preserving the acceptable content of heavy metals in this waste and maintaining sanitary safety $[2,15]$.

Sludge coming from rural sewage treatment plants that receive mainly domestic wastewater can be useful in cultivation of cereals intended for consumption, feed or energy purposes. As a rule, municipal sewage from rural sewage systems is not burdened with chemical contaminants, and after purification, the obtained sewage sludge will be "pure" in terms of heavy metals and not burdened with microbiological contaminants [16, 17].

The use of municipal sewage sludge in cultivation of cereals provides a possibility to recover nutrients from this waste. In addition, sewage sludge from rural sewage treatment plants can be an alternative for natural fertilizers [18]. In addition, application of sewage sludge improves soil chemical properties by, among other things, increasing the content of organic matter, available macroelements $[19,20]$.

The aim of the research was to assess the effect of municipal sewage sludge on soil chemical properties as well as on chemical composition of spring wheat. The conducted field experiment was also supposed to reflect in a tangible way the effect of this waste on the chemical composition of spring wheat biomass. The aim of the research was reached under field experiment conditions because research conducted in this way most faithfully reflects natural conditions under which processes of chemical changes and mineralization take place, and these processes affect chemical composition of plants. Also for cognitive purposes, this paper presents the ratios between elements present in spring wheat fertilized with mineral fertilizers and sewage sludge.

\section{Materials and methods}

The research was conducted on two production fields (1 ha each), in a plant production farm. The research was conducted in the commune Iwanowice located in the Malopolska province, in southern Poland.

\section{Soil and municipal sewage sludge}

Basic physicochemical properties of the soil prior to setting up the field experiment and of municipal sewage sludge are provided in Table 1.

The soil on which the field experiment was set up was classified into brown soils, and in terms of granulometric composition - into silt [21]. The soil reaction was slightly acid, and organic carbon content in the soil did not deviate from average values for cultivated soils [22]. The content of available forms of $\mathrm{P}, \mathrm{K}$ and $\mathrm{Mg}$ in the soil was at a medium level. Heavy metal content in the cultivable soil did not exceed acceptable values at agricultural use of municipal sewage sludge, and it was below acceptable values specified in standards for soil quality and ground quality standards [15, 23, 24]. 
Physicochemical properties of soil and municipal sewage sludge

\begin{tabular}{|c|c|c|c|}
\hline Parameter & Unit & $\begin{array}{c}\text { Content } \\
\text { in the soil layer } \\
0-25 \mathrm{~cm}\end{array}$ & $\begin{array}{c}\text { Municipal } \\
\text { sewage sludge }\end{array}$ \\
\hline Fraction 2-0.05 mm & \multirow{3}{*}[\%]{} & 11 & - \\
\hline Fraction $0.05-0.002 \mathrm{~mm}$ & & 56 & - \\
\hline Fraction $0.002 \mathrm{~mm}$ & & 33 & - \\
\hline Dry matter & {$[\%]$} & - & 18.3 \\
\hline $\mathrm{pH}_{(\mathrm{H} 2 \mathrm{O})}$ & \multirow{2}{*}{-} & 6.48 & 9.14 \\
\hline $\mathrm{pH}_{(\mathrm{KCl})}$ & & 6.34 & - \\
\hline Organic carbon & [g/kg d.m.] & 28.7 & 569 \\
\hline Chromium & \multirow{7}{*}{ [mg/kg d.m.] } & 18.9 & 23.6 \\
\hline Zinc & & 64.2 & 1219 \\
\hline Lead & & 21.7 & 77.0 \\
\hline Copper & & 11.6 & 200 \\
\hline Cadmium & & 1.28 & 8.21 \\
\hline Nickel & & 12.6 & 14.5 \\
\hline Mercury & & 0.050 & 0.660 \\
\hline Available phosphorus & \multirow{3}{*}{ [mg/kg d.m.] } & 46.2 & - \\
\hline Available potassium & & 129 & - \\
\hline Available magnesium & & 65.4 & - \\
\hline Total nitrogen & \multirow{6}{*}{ [g/kg d.m.] } & 1.77 & 35.8 \\
\hline Total phosphorus & & 0.46 & 15.0 \\
\hline Total potassium & & 7.23 & 2.30 \\
\hline Total sodium & & 0.22 & 1.22 \\
\hline Total calcium & & 12.7 & 74.4 \\
\hline Total magnesium & & 1.65 & 5.70 \\
\hline
\end{tabular}

Municipal sewage sludge, as organic waste with catalogue number 190805 came from the sewage treatment plant in the commune of Iwanowice [25]. The sewage sludge was stabilized (aerobic stabilization) and hygienised with burnt lime. The content of heavy metals in the municipal sewage sludge did not exceed acceptable values at its agricultural use (Table 1). No Salmonella bacteria or live eggs of intestinal parasites were detected in the used municipal sewage sludge [15].

\section{Scheme and conditions of conducting the field experiment}

The experimental design comprised two treatments. In the control treatment (1), only mineral fertilization in the amount of $150: 70: 150 \mathrm{~kg}$ NPK/ha was applied. Nitrogen was applied in the following doses: $60 \mathrm{~kg} / \mathrm{ha}$ pre-sowing $+60 \mathrm{~kg} / \mathrm{ha}$ at the beginning of stem elongation $(\mathrm{BBCH} 31)+30 \mathrm{~kg} / \mathrm{ha}$ at the beginning of heading $(\mathrm{BBCH} 51)$. Nitrogen fertilizer was applied in the form of ammonium nitrate $(34 \% \mathrm{~N})$, phosphorus fertilizer - in the form of triple superphosphate $\left(46 \% \mathrm{P}_{2} \mathrm{O}_{5}\right)$, and potassium - in the form of potassium salt $\left(50 \% \mathrm{~K}_{2} \mathrm{O}\right)$. Mineral fertilization with $\mathrm{PK}$ was applied in autumn, before pre-winter plowing.

In the treatment with sludge (2), municipal sewage sludge was applied in a dose of $23 \mathrm{Mg} / \mathrm{ha}$ of fresh matter, which corresponded to $4.21 \mathrm{Mg} / \mathrm{ha}$ d.m.

The municipal sewage sludge was applied once on the surface of the experimental plot, then mixed with a soil layer at the depth of $25 \mathrm{~cm}$. The municipal sewage sludge was distributed in the autumn with a manure spreader, and then pre-winter plowing was done. 
In total, $150.68 \mathrm{~kg}$ nitrogen, $63.14 \mathrm{~kg}$ phosphorus, and $9.68 \mathrm{~kg} / \mathrm{ha}$ potassium were introduced to the soil with the dose of $23 \mathrm{Mg}$ of fresh matter. The amount of municipal sewage sludge applied under spring wheat corresponded with the nitrogen requirement.

It is assumed that utilization of nitrogen from municipal sewage sludge by cultivated plants amounts to approximately $60 \%$ in the first year. That is why, aside from fertilization with sewage sludge, supplementary mineral fertilization should be applied [26]. It was assumed that nitrogen use by spring wheat from this waste would be approximately $90 \mathrm{~kg} / \mathrm{ha}$, therefore in the treatment with sludge (2) mineral nitrogen fertilization was supplemented to the level used in the control treatment (1). Nitrogen was also applied in three doses: $20 \mathrm{~kg} / \mathrm{ha}$ pre-sowing $+20 \mathrm{~kg} / \mathrm{ha}$ at the beginning of stem elongation $(\mathrm{BBCH} 31)+20 \mathrm{~kg} / \mathrm{ha}$ at the beginning of heading $(\mathrm{BBCH} 51)$. It was also assumed in the experiment that utilization of $\mathrm{P}$ and $\mathrm{K}$ from sewage sludge would be at the level of $30 \%$. That is why in the treatment with sludge (2), mineral fertilization was supplemented with these macroelements to the level used in the control treatment (1).

"Banti" cultivar spring wheat was sown in the spring (third decade of March), at a density of 500 germinating grains per $1 \mathrm{~m}^{2}$. Spring rape was the forecrop for spring wheat. During vegetation, Chwastox Extra 300 SL was used for weed control, Alfamor 050 SC for pest control, and Alert 375 SC was used for disease control. Pesticides were applied in accordance with manufacturer's instructions. Spring wheat was harvested in a single stage, at full maturity, in the third decade of August.

\section{Methods of determinations}

Samples of plant and soil material from 4 random areas (each covering $15 \mathrm{~m}^{2}$ ) were collected from each production field (control - 1, and treatment with sewage sludge - 2). Soil samples were collected from a 0-25 cm layer.

Once the spring wheat was collected, the plant material was dried in a forced air circulation dryer at $105{ }^{\circ} \mathrm{C}$, according to the widely adopted methodology of chemical-agricultural analysis. After drying, the yield of air-dry plant material was determined and expressed in $\mathrm{Mg} / \mathrm{ha}$ d.m. The plant samples were then subjected to dry mineralization in a muffle furnace at $600{ }^{\circ} \mathrm{C}$. The content of macronutrients $(\mathrm{P}, \mathrm{K}, \mathrm{Na}, \mathrm{Mg}$, Ca) from plant ash was dissolved in $1 \mathrm{~mol} \mathrm{HCl}$ and transferred to $50 \mathrm{~cm}^{3}$ volumetric flasks [27].

The soil material was dried in a forced air circulation dryer at $70{ }^{\circ} \mathrm{C}$. After drying, $\mathrm{pH}$ was determined in the soil material, by potentiometric method in distilled water, in $1 \mathrm{~mol} / \mathrm{dm}^{3} \mathrm{KCl}$; organic carbon - by Tiurin method; available phosphorus and potassium by Egner-Riehm method; and available magnesium - by Schachtschabel method. The total content of macronutrients $(\mathrm{P}, \mathrm{K}, \mathrm{Na}, \mathrm{Mg}, \mathrm{Ca})$ in the soil was extracted in a mixture of concentrated acids: $\mathrm{HNO}_{3}$ and $\mathrm{HClO}_{4}(3: 2, \mathrm{v} / \mathrm{v})$. After mineralization of the plant and soil material, the content of the macronutrients was determined using ICP-AES spectrometer [28]. The content of total $\mathrm{N}$ in the plant and soil material was determined by Kjeldahl method.

\section{Quality control of analyses}

Determination in each of the studied samples was done in triplicate. The accuracy of the analytical method was verified against certified reference materials and standard solutions: BCR-129 - Hay Powder (IRMM - Institute for Reference Materials and Measurements). 


\section{Computations and statistical analysis of the results}

The following parameters were assumed as the basis for determining the uptake of macronutrients by spring wheat:

- yield $Y$;

- content of macronutrients in grain and straw $C$;

- $\quad$ uptake of macronutrients $U$, by wheat - calculated as a product of dry matter yield $Y$ and the content $C$ of the element, according to the formula:

$$
U=Y \cdot C
$$

This paper presents the balance $B$ of macroelements, which was calculated from the difference between the amount of macroelements applied, $A$ with the dose of mineral fertilizers and sewage sludge, and the amount of macroelements uptaken with plant yield. The uptake was calculated according to the formula:

$$
B=A-U
$$

The simplified balance did not take into account the inflow of macroelements with precipitation or leaching of these elements deep into the soil profile. Phytoremediation of macroelements presented in the balance is the percentage share of the uptake of these elements in relation to the amount of elements introduced to soil along with mineral fertilizers and sewage sludge.

This paper also presents quantitative ratios between the studied nutrients in spring wheat biomass. $\mathrm{Ca}: \mathrm{P}, \mathrm{Ca}: \mathrm{Mg}, \mathrm{K}: \mathrm{Na}$ mass ratios, as well as $\mathrm{K}:(\mathrm{Ca}+\mathrm{Mg}), \mathrm{K}: \mathrm{Mg}$ and $\mathrm{K}: \mathrm{Ca}$ equivalent ratios were calculated.

The statistical analysis of the research results was carried out using a Microsoft Office Excel 2007 spreadsheet and Statistica version 12 PL software package. The statistical assessment of variability of results was carried out using single-factor analysis of variance, separately for grain and straw. Significance of differences between mean values was verified using t-Student test at a significance level of $\alpha \leq 0.05$. For selected parameters (ratios), the value of Pearson's linear correlation coefficient $r$ was computed, at a significance level of $p<0.05$. The maximum $5 \%$ dispersion between measurements in chemical analysis was adopted.

\section{Results and discussion}

Under the influence of microorganisms, chemical compounds introduced to the soil with sewage sludge undergo complex processes: mineralization, sorption, immobilization, nitrification, denitrification, volatilization into the atmosphere, uptake by plants, and leaching into the soil profile [19, 20, 29]. The use of municipal sewage sludge in agriculture contributes to the improvement of soil chemical properties and to the increase in yield of cultivated plants $[2,18]$.

\section{Soil chemical properties}

There was no difference in the impact of mineral fertilization (in a dose of $150: 70: 150 \mathrm{~kg} \mathrm{NPK} / \mathrm{ha}$ ) and sewage sludge application (in a dose of $23 \mathrm{Mg} / \mathrm{ha}$ fresh matter) on soil properties (Table 2). The field experiment with spring wheat showed that application of municipal sewage sludge did not have an effect on soil $\mathrm{pH}$. Other authors' studies $[19,26]$ have confirmed that sewage sludge does not always influence soil $\mathrm{pH}$. Municipal sewage sludge applied in the experiment was alkaline, its $\mathrm{pH}$ was 9.14 , and with 
the dose of $23 \mathrm{Mg}$ of fresh matter more than $313 \mathrm{~kg} / \mathrm{ha}$ calcium was introduced to the soil. Introduction of this alkaline element might have compensated soil acidification that was a result of, among other things, intensive mineralization of sewage sludge organic matter. As it was stated by Cukjati et al. [30], using organic waste in the form of sewage sludge and composts introduces organic substance and nitrogen to the soil, which favors the improvement of soil chemical properties. Our research did not show any differences in organic carbon content, total nitrogen content or in the value of $\mathrm{C}: \mathrm{N}$ ratio in soil with only mineral fertilization and with sewage sludge application.

Table 2

Chemical properties of the soil from experimental fields

\begin{tabular}{|c|c|c|c|c|c|c|c|c|}
\hline \multirow{3}{*}{ Treatment $^{*}$} & \multicolumn{2}{|c|}{ pH } & \multirow{2}{*}{ C org. } & \multirow{2}{*}{$\mathrm{N}$ total } & \multirow{3}{*}{$\begin{array}{l}C: N \\
\text { ratio }\end{array}$} & \multicolumn{3}{|c|}{ Available forms } \\
\hline & \multirow{2}{*}{$\mathrm{H}_{2} \mathrm{O}$} & \multirow{2}{*}{ KCl } & & & & $\mathbf{P}$ & $\mathbf{K}$ & Mg \\
\hline & & & \multicolumn{2}{|c|}{ [g/kg d.m.] } & & \multicolumn{3}{|c|}{ [mg/kg d.m.] } \\
\hline 1 & $6.46 a^{* * *}$ & $6.30 \mathrm{a}$ & $28.5 \mathrm{a}$ & $1.80 \mathrm{a}$ & $15.9 \mathrm{a}$ & $50.5 \mathrm{a}$ & $139 \mathrm{a}$ & $62.8 \mathrm{a}$ \\
\hline 2 & $6.49 a$ & $6.36 \mathrm{a}$ & $29.4 a$ & $1.81 \mathrm{a}$ & $16.3 \mathrm{a}$ & $52.1 \mathrm{a}$ & $150 \mathrm{a}$ & $62.9 \mathrm{a}$ \\
\hline
\end{tabular}

* 1 - only mineral fertilization $150: 70: 150 \mathrm{~kg} \mathrm{NPK} \cdot \mathrm{ha}^{-1} ; 2$ - municipal sewage sludge applied in a dose of $23 \mathrm{Mg} \cdot \mathrm{ha}^{-1}$ of fresh matter + mineral fertilization

*** values labeled with the same letters do not differ significantly among themselves according to Tukey's test, at a significance level of $\alpha \leq 0.05$

The applied municipal sewage sludge contained over 33, 5, 5, 3-fold more total P, Na, $\mathrm{Ca}$, and $\mathrm{Mg}$, respectively, compared with the content in the soil (Table 1). Only total $\mathrm{K}$ content in the soil was over 3 -fold higher than in the sewage sludge. The field experiment showed that application of mineral fertilization and municipal sewage sludge had statistically the same effect on the content of available $\mathrm{P}, \mathrm{K}$ and $\mathrm{Mg}$ in the soil (Table 2). At the same time, the soil of both fertilizer treatments had a slightly higher content of available $\mathrm{P}$ and $\mathrm{K}$ than the soil prior to setting up the field experiment. Sewage sludge is a potential source of nutrients $[31,32]$, which may translate into an increase in the content of available macronutrients in soil after sewage sludge application. From the basic nutrients present in sewage sludge, phosphorus is the best absorbed by soil, whereas potassium - the least. The content of available phosphorus in soil is a factor that depends on soil reaction. In soil with $\mathrm{pH}$ below 6 , aluminum and iron phosphate (which are not readily available for plants) are formed, and at $\mathrm{pH}$ above 7.5 - non-available calcium phosphates are formed [33]. This research did not show that soil reaction was favorable for a significant increase in the amount of available phosphorus in soil.

\section{Spring wheat yield}

Mineral fertilization and fertilization with sewage sludge (treatment 2) had a beneficial effect on spring wheat yield. Grain and straw yield from the control treatment (1) amounted to 4.36 and $5.22 \mathrm{Mg} / \mathrm{ha}$, respectively (Table 3). Grain and straw yield from the treatment where municipal sewage sludge and supplementary mineral fertilization had been applied amounted to 4.56 and $5.59 \mathrm{Mg} / \mathrm{ha}$, respectively. The research shows that spring wheat yield in the treatment fertilized with sewage sludge was much higher than in the control. The obtained difference in grain and straw yield between treatments amounted to 5 and $7 \%$. The effect of mineral and organic fertilization on wheat yielding had been confirmed in earlier studies [26, 34, 35]. The applied sewage sludge did not improve soil chemical properties but indirectly increased spring wheat yield. Other studies have shown that 
organic fertilization does not always improve the amount of yield of cultivated plants [36]. In the study by Deeks et al. [18], it was shown that mineral fertilization increased spring wheat yield compared with organic-mineral fertilization.

Content and uptake of macronutrients by spring wheat

Table 3

\begin{tabular}{|c|c|c|c|c|c|c|c|c|}
\hline \multirow{2}{*}{ Treatment ${ }^{*}$} & \multirow{2}{*}{$\begin{array}{c}\text { Plant } \\
\text { part }\end{array}$} & \multirow{2}{*}{$\begin{array}{c}\text { Yield } \\
{[\mathrm{Mg} / \mathrm{ha}]}\end{array}$} & \multicolumn{6}{|c|}{ Content [g/kg d.m.] } \\
\hline & & & $\mathbf{N}$ & $\mathbf{P}$ & $\mathbf{K}$ & $\mathrm{Na}$ & Mg & $\mathbf{C a}$ \\
\hline 1 & \multirow{2}{*}{ Grain } & $4.36 \mathrm{a}^{* *}$ & $21.14 \mathrm{a}$ & $3.93 a$ & $3.69 \mathrm{a}$ & $1.68 \mathrm{a}$ & $1.92 \mathrm{a}$ & $2.08 \mathrm{a}$ \\
\hline 2 & & $4.56 \mathrm{~b}$ & $18.54 \mathrm{~b}$ & $3.65 b$ & $3.38 \mathrm{~b}$ & $1.50 \mathrm{~b}$ & $1.75 \mathrm{~b}$ & $1.73 \mathrm{a}$ \\
\hline 1 & \multirow{2}{*}{ Straw } & $5.22 \mathrm{a}$ & $6.18 \mathrm{a}$ & $1.55 \mathrm{a}$ & $9.69 \mathrm{a}$ & $1.99 \mathrm{a}$ & $1.21 \mathrm{a}$ & $4.12 \mathrm{a}$ \\
\hline 2 & & $5.59 \mathrm{~b}$ & $4.95 \mathrm{~b}$ & $1.18 \mathrm{~b}$ & $8.88 \mathrm{~b}$ & $1.79 \mathrm{~b}$ & $1.10 \mathrm{~b}$ & $3.69 \mathrm{~b}$ \\
\hline & & & \multicolumn{6}{|c|}{ Uptake [kg/ha] } \\
\hline 1 & \multirow{2}{*}{ Grain } & - & $92.34 \mathrm{a}$ & $17.13 \mathrm{a}$ & $16.13 a$ & $7.33 a$ & $8.39 a$ & $9.09 \mathrm{a}$ \\
\hline 2 & & - & $96.71 \mathrm{a}$ & $19.02 b$ & $17.61 \mathrm{a}$ & $7.82 \mathrm{a}$ & $9.13 a$ & $9.01 \mathrm{a}$ \\
\hline 1 & \multirow{2}{*}{ Straw } & - & $28.19 \mathrm{a}$ & $7.08 \mathrm{a}$ & $44.22 \mathrm{a}$ & $9.06 \mathrm{a}$ & $5.52 \mathrm{a}$ & $18.78 \mathrm{a}$ \\
\hline 2 & & - & $27.72 \mathrm{a}$ & $6.59 \mathrm{a}$ & $49.51 \mathrm{a}$ & $9.98 b$ & $6.16 \mathrm{~b}$ & $20.63 a$ \\
\hline
\end{tabular}

\section{Content of macroelements in spring wheat}

Agricultural use of sewage sludge consists in using it for soil fertilization and supplying plants with nutrients [2]. The content of macronutrients in spring wheat fertilized with mineral fertilizers and sewage sludge is provided in Table 3. These data indicate that, regardless of fertilization treatment, there was more $\mathrm{N}, \mathrm{P}$ and $\mathrm{Mg}$ in wheat grain than in straw, while there was more $\mathrm{K}, \mathrm{Na}$ and $\mathrm{Ca}$ in straw than in grain. Studies by Hamner et al. [37] confirm that more $\mathrm{N}, \mathrm{P}$ and $\mathrm{Mg}$ is accumulated in grains of cereals than in straw. Studies by Matraszek et al. [38] as well as Doltra et al. [39] also confirm that cereal straw contains more $\mathrm{K}$ and $\mathrm{Na}$, and when this plant part is intended for energy purposes, the above-mentioned elements can accelerate corrosion of biomass burning boilers [40].

The municipal sewage sludge applied in a dose of $23 \mathrm{Mg} / \mathrm{ha}$ of fresh matter increased the spring wheat biomass yield, which caused dilution of macronutrients in this plant. The dilution led to a significant decrease in the content of $\mathrm{N}, \mathrm{P}, \mathrm{K}, \mathrm{Na}, \mathrm{Mg}$ and $\mathrm{Ca}$ in grain and straw of spring wheat. The decrease in content of the above-mentioned macronutrients in grain was, respectively, over $12,7,8,10,9,16 \%$ in relation to the control treatment. The decrease in the content of $\mathrm{N}, \mathrm{P}, \mathrm{K}, \mathrm{Na}, \mathrm{Mg}$ and $\mathrm{Ca}$ was observed in spring wheat straw too, and it was, respectively, over $20,24,8,10,9,10 \%$ in relation to the control treatment. Other authors' studies $[26,41]$ confirm that sewage sludge increases yield and reduces the content of macronutrients in cultivated and energy plants.

The field experiment also showed close relationships between spring wheat yield and the content of $\mathrm{N}, \mathrm{P}, \mathrm{Mg}$ and $\mathrm{Ca}$ in grain and straw of this plant $(r=0.7205-0.9108)$.

Chemical composition of plants is an important index of yield quality [37,38]. It is assumed that good quality feed should contain approximately 7-18 g N, 1.7-4.5 g P, 6.0-12 g K, 2-8 g Ca, 1-2.5 g Mg, and 1.5-2.5 g Na/kg d.m. [42, 43]. While estimating feed value of spring wheat cultivated on the sewage sludge, it was established that content $\mathrm{P}, \mathrm{Na}$, $\mathrm{Mg}$ and $\mathrm{Ca}$ in grain was within the optimal value range, whereas the content of $\mathrm{K}$ was lower than optimal. The research shows that municipal sewage sludge did not worsen the 
quality of the chemical composition of spring wheat grain, which has been confirmed in studies by Gondek [26] and other authors [44].

\section{Uptake of macronutrients by spring wheat}

The research revealed that spring wheat grain took up more $\mathrm{N}, \mathrm{P}, \mathrm{Mg}$ compared with straw, whereas straw took up more $\mathrm{K}, \mathrm{Na}$ and $\mathrm{Ca}$ (Table 3). Application of municipal sewage sludge significantly increased $\mathrm{P}$ uptake by grain, and $\mathrm{Na}$ and $\mathrm{Mg}$ uptake by spring wheat straw.

Uptake of $\mathrm{N}, \mathrm{P}, \mathrm{K}, \mathrm{Na}$ and $\mathrm{Mg}$ by spring wheat grain obtained in the treatment fertilized with sewage sludge was higher by over $4,11,9,6,8 \%$, respectively, compared to the control. Fertilization with sewage sludge significantly increased $\mathrm{Na}$ and $\mathrm{Mg}$ uptake by spring wheat straw; that increase reached, respectively, over 10 and $11 \%$ in relation to the control treatment. Other authors' studies [44] have shown that mineralization of sewage sludge lasts so long that even during grain formation plants can take up nutrients (from decomposition) from soil.

In terms of quantity of macronutrients taken up by grain in the control treatment (which was fertilized only with mineral fertilizers), the series is as follows: $\mathrm{N}>\mathrm{P}>\mathrm{K}>\mathrm{Ca}$ $>\mathrm{Mg}>\mathrm{Na}$. In the treatment fertilized with sewage sludge, that series changed due to the amount of Mg uptake: $\mathrm{N}>\mathrm{P}>\mathrm{K}>\mathrm{Mg}>\mathrm{Ca}>\mathrm{Na}$. The presented series show that from the studied macronutrients grain accumulated the highest amount of $\mathrm{N}$, and the lowest amount of Na. Spring wheat straw, harvested from the treatment fertilized with sewage sludge, took up most $\mathrm{K}$, followed by $\mathrm{N}>\mathrm{Ca}>\mathrm{Na}>\mathrm{P}>\mathrm{Mg}$.

In the treatment fertilized with sewage sludge (treatment 2), it was established that the percentage of the uptake of $\mathrm{N}, \mathrm{P}, \mathrm{Mg}$ by spring wheat grain in the total yield was, respectively, 77, 74, $59 \%$. The percentage of the uptake of $\mathrm{K}, \mathrm{Na}$ and $\mathrm{Ca}$ by spring wheat straw in the total yield reached, respectively, 73, 56, 69\%. The research shows that spring wheat grain takes up mainly $\mathrm{N}, \mathrm{P}$ and $\mathrm{Mg}$, whereas straw - K, Na and $\mathrm{Ca}$. Other authors' studies confirm that cereal straw can be an effective organ responsible for the uptake (phytoextraction) of alkaline constituents [10].

Taking into account the total uptake of macronutrients by grain and straw, it was established that spring wheat cultivated on sewage sludge took up more of the studied macronutrients compared with the control treatment. Studies by Gondek [26], Gilbert et al. [41] and Guedes et al. [32] confirm that sewage sludge is a valuable source of macronutrients.

Strong relationships between plant yield and the uptake of $\mathrm{P}, \mathrm{K}, \mathrm{Mg}$ by spring wheat grain ( $r=0.7094-0.9043)$ as well as the uptake of $\mathrm{K}, \mathrm{Na}, \mathrm{Mg}$ and $\mathrm{Ca}$ by spring wheat straw ( $r=0.7750-0.9291)$ were also shown in the experiment. The above correlations have a significant importance in the quality of biomass intended for phytoremediation or energy purposes.

\section{Simplified balance and utilization of macronutrients}

When using municipal sewage sludge for fertilization of cultivated plants, we introduce macronutrients (which can be incorporated into biomass) to the environment. Understanding the cycling of macronutrients in the soil-plant system will allow for a better assessment of the risk connected with the use of these organic wastes in fertilization. This assessment can be done on an approximate basis, based on, among other things, the simplified balance of macroelements and based on their use (phytoremediation). Earlier 
studies by Antonkiewicz et al. [9] as well as by Bien et al. [16] confirm the need to understand the cycling and the use (recycling) of elements from organic waste.

The effect of macronutrient balance was determined by the dose of mineral fertilizer and sewage sludge (the amount of nutrients introduced) and by total macronutrient uptake with the yield of spring wheat biomass (Table 4). N, P and $\mathrm{K}$ balance in the control treatment where only mineral fertilization was applied was positive, and $\mathrm{Na}, \mathrm{Mg}$ and $\mathrm{Ca}$ balance was negative. The positive $\mathrm{N}, \mathrm{P}$ and $\mathrm{K}$ balance resulted from the influx of these elements with mineral fertilizers, whereas the negative $\mathrm{Na}, \mathrm{Mg}$ and $\mathrm{Ca}$ balance was due to lack of influx of these macronutrients with fertilizers and simultaneous uptake by plants. Application of municipal sewage sludge with mineral fertilizers (treatment 2) had an effect on $\mathrm{N}, \mathrm{P}, \mathrm{K}, \mathrm{Mg}$ and $\mathrm{Ca}$ balance (positive balance), and on the $\mathrm{Na}$ balance (negative balance). The positive macronutrient balance $(\mathrm{N}, \mathrm{P}, \mathrm{K}, \mathrm{Mg}$ and $\mathrm{Ca}$ ) resulted from a higher amount of nutrients introduced with fertilizers compared with the amounts taken up with spring wheat yield. It is important to highlight that the high positive balance for $\mathrm{N}, \mathrm{P}$ and $\mathrm{K}$ indicates that the applied fertilization was too high in relation to wheat nutritional demands and may pose a risk to the environment (e.g. high outflow of $\mathrm{N}$ and $\mathrm{P}$ from agricultural sources contributes to eutrophication of the environment).

Simplified macronutrient balance after experiment completion

\begin{tabular}{|c|c|c|c|c|}
\hline Treatment ${ }^{*}$ & $\begin{array}{c}\text { Introduced } \\
{[\mathrm{kg} / \mathrm{ha}]}\end{array}$ & $\begin{array}{l}\text { Uptake } \\
{[\mathrm{kg} / \mathrm{ha}]}\end{array}$ & $\begin{array}{l}\text { Balance } \\
{[\mathrm{kg} / \mathrm{ha}]}\end{array}$ & $\begin{array}{c}\text { Recovery } \\
{[\%]}\end{array}$ \\
\hline \multicolumn{5}{|c|}{$\mathrm{N}$} \\
\hline 1 & 150.0 & 120.5 & 29.5 & 80.3 \\
\hline 2 & 150.7 & 124.4 & 26.3 & 82.5 \\
\hline \multicolumn{5}{|c|}{$\mathrm{P}$} \\
\hline 1 & 70 & 24.2 & 45.8 & 34.6 \\
\hline 2 & 70 & 25.6 & 44.4 & 36.6 \\
\hline \multicolumn{5}{|c|}{$\mathrm{K}$} \\
\hline 1 & 150 & 60.3 & 89.7 & 40.2 \\
\hline 2 & 150 & 67.1 & 82.9 & 44.7 \\
\hline \multicolumn{5}{|c|}{$\mathrm{Na}$} \\
\hline 1 & 0 & 16.4 & -16.4 & - \\
\hline 2 & 5.13 & 17.8 & -12.7 & - \\
\hline \multicolumn{5}{|c|}{$\mathrm{Mg}$} \\
\hline 1 & 0 & 13.9 & -13.9 & - \\
\hline 2 & 24.0 & 15.3 & 8.7 & 63.7 \\
\hline \multicolumn{5}{|c|}{$\mathrm{Ca}$} \\
\hline 1 & 0 & 27.9 & -27.9 & - \\
\hline 2 & 313.1 & 29.6 & 283.5 & 9.5 \\
\hline
\end{tabular}

see Table 2

Application of municipal sewage sludge slightly increased the use (phytoremediation) of macronutrients by spring wheat compared to the control treatment. This research proves that mineral fertilizers can be partially substituted with sewage sludge because recovery of these nutrients is comparable, which finds confirmation in other papers [6, 18]. Moreover, organic-mineral fertilizers guarantee a slow release of nutrients for cultivated plants, which leads to an increased nutrient use [18, 45].

When comparing the percent use (phytoremediation) of macronutrients by spring wheat, regardless of treatment, the following order can be established (from the highest to 
the lowest value): $\mathrm{N}$ (over $80 \%$ ), Mg (over $63 \%$ ), K (over $40 \%$ ), P (over $34 \%$ ), Ca (9\%). The above series indicates that $\mathrm{N}$ was recovered by spring wheat to the greatest extent, and $\mathrm{Ca}$ - to the lowest extent. The obtained research results confirm that spring wheat uses nitrogen from mineral and organic fertilizers well [46]. Research conducted by Mayer et al. [36] confirms that organic fertilization increases the effectiveness of nitrogen use by cultivated plants, including wheat.

\section{Ratios between elements in spring wheat grain and straw}

Interrelationships between elements in plants constitute an important qualitative aspect for biomass yield [42]. In the case of application of municipal sewage sludge, there is a concern that this waste can affect the quality of plant chemical composition [26, 47]. In this research, regardless of the type of fertilization (treatment), spring wheat straw was observed to have significantly higher values of ratios between macronutrients in comparison with values in grain (Table 5). A small range of variability of these ratios between macronutrients in grain and straw of spring wheat was noticed. The above analysis indicates that spring wheat grain and straw, obtained regardless of the type of fertilization (treatment), were characterized by stable proportions between these elements.

Table 5

Ratios between macroelements in spring wheat grain and straw

\begin{tabular}{|c|c|c|c|c|c|c|c|}
\hline Treatment $^{*}$ & Plant part & Ca: $\mathbf{P}$ & $\mathrm{Ca}: \mathrm{Mg}$ & $\mathrm{K}: \mathrm{Na}$ & $\mathrm{K}:(\mathrm{Ca}+\mathrm{Mg})$ & $\mathrm{K}: \mathrm{Mg}$ & $\mathbf{K}: \mathbf{C a}$ \\
\hline 1 & \multirow{2}{*}{ Grain } & $0.53 b^{* *}$ & $1.08 \mathrm{a}$ & $2.20 \mathrm{a}$ & $0.36 \mathrm{a}$ & $0.60 \mathrm{a}$ & $0.91 \mathrm{a}$ \\
\hline 2 & & $0.48 \mathrm{a}$ & $0.99 \mathrm{a}$ & $2.26 \mathrm{a}$ & $0.37 \mathrm{a}$ & $0.60 \mathrm{a}$ & $1.01 \mathrm{a}$ \\
\hline 1 & \multirow{2}{*}{ Straw } & $2.66 a$ & $3.41 \mathrm{a}$ & $4.88 \mathrm{a}$ & $0.81 \mathrm{a}$ & $2.49 a$ & $1.21 \mathrm{a}$ \\
\hline 2 & & $3.15 b$ & $3.35 \mathrm{a}$ & $4.98 \mathrm{a}$ & $0.83 a$ & $2.50 \mathrm{a}$ & $1.24 \mathrm{a}$ \\
\hline
\end{tabular}

Application of municipal sewage sludge significantly decreased the value of $\mathrm{Ca}: \mathrm{P}$ ratio in spring wheat grain compared to the control treatment. On the other hand the application of municipal sewage sludge significantly increased $\mathrm{Ca}: \mathrm{P}$ ratio value in spring wheat straw. Application of sewage sludge did not cause a significant change in the values of $\mathrm{Ca}: \mathrm{Mg}, \mathrm{K}: \mathrm{Na}, \mathrm{K}:(\mathrm{Ca}+\mathrm{Mg}), \mathrm{K}: \mathrm{Mg}$ and $\mathrm{K}: \mathrm{Ca}$ ratios in spring wheat grain and straw compared to the control treatment.

The experiment showed that $\mathrm{Ca}: \mathrm{P}, \mathrm{Ca}: \mathrm{Mg}$ and $\mathrm{K}: \mathrm{Ca}$ ratios in spring wheat grain were strongly correlated with $\mathrm{Ca}$ content in this part of the plant, whereas $\mathrm{Ca}: \mathrm{P}$ ratio in straw was strictly correlated not only with $\mathrm{Ca}$ content, but also with $\mathrm{N}$ and $\mathrm{P}$ content in spring wheat straw.

The obtained chemical composition of biomass of spring wheat was evaluated based on criteria of the feed nutrient value, according to which the optimal ratios of $\mathrm{Ca}: \mathrm{P}$, $\mathrm{Ca}: \mathrm{Mg}, \mathrm{K}: \mathrm{Na}, \mathrm{K}:(\mathrm{Ca}+\mathrm{Mg}), \mathrm{K}: \mathrm{Mg}, \mathrm{K}: \mathrm{Ca}$ should amount to $2: 1 ; 2-3: 1 ; 10: 1$; $1.6-2.2: 1 ; 6: 1 ; 2: 1$, respectively [42, 48, 49]. When determining the chemical composition of spring wheat grain, it was established that the analyzed values of ratios between elements were below optimal values. In the case of straw it was also established that values of $\mathrm{K}: \mathrm{Na}, \mathrm{K}:(\mathrm{Ca}+\mathrm{Mg}), \mathrm{K}: \mathrm{Mg}$ and $\mathrm{K}: \mathrm{Ca}$ ratios were below optimal. Only the values of $\mathrm{Ca}: \mathrm{P}$ and $\mathrm{Ca}: \mathrm{Mg}$ ratios in spring wheat straw were above optimal values. Research conducted by Gondek [26] confirms that application of municipal sewage sludge and other organic fertilizers did not have a significant effect on the value of $\mathrm{K}: \mathrm{Mg}$ ratio in 
wheat grain, but the author observed significant changes in ratios between $\mathrm{N}: \mathrm{S}$ and $\mathrm{P}: \mathrm{Zn}$ due to organic fertilization. Other research [38] showed that the heavy metal treatment had a significant effect on the value of ratios between macroelements in wheat. Moreover, ratios between elements are of significant importance in the quality of biomass intended also for energy purposes $[6,50]$.

\section{Conclusions}

The applied municipal sewage sludge in a dose of $23 \mathrm{Mg} / \mathrm{ha}$ fresh matter per hectare did not significantly change soil chemical properties. Application of municipal sewage sludge significantly increased biomass yield of spring wheat. Fertilization with sewage sludge significantly decreased macronutrient content in spring wheat grain and straw compared to the treatment fertilized only with mineral fertilizers. Application of municipal sewage sludge significantly increased $\mathrm{P}$ uptake by grain, and $\mathrm{Na}$ and $\mathrm{Mg}$ uptake by spring wheat straw. Utilization of $\mathrm{N}, \mathrm{Mg}, \mathrm{K}, \mathrm{P}$ and $\mathrm{Ca}$ from municipal sewage sludge by spring wheat was at a level of over $82,63,44,36,9 \%$, respectively, of the amount introduced with the organic waste. Values of ratios between elements in spring wheat grain and straw were below optimal values. Only the values of $\mathrm{Ca}: \mathrm{P}$ and $\mathrm{Ca}: \mathrm{Mg}$ ratios in spring wheat straw were above optimal values. Municipal sewage sludge from rural sewage treatment plants can be used for fertilization of cereals, provided that environmental standards are kept.

\section{Acknowledgments}

The research results carried out within the subject No. 3101 were financed from the subsidy for science granted by the Polish Ministry of Science and Higher Education.

\section{References}

[1] Lamastra L, Suciu NA, Trevisan M. Chem Biol Technol Agric. 2018;5:10. DOI: 10.1186/s40538-018-0122-3.

[2] Alvarenga P, Mourinha C, Farto M, Santos T, Palma P, Sengo J, et al. Waste Manage. 2015;40:44-52. DOI: 10.1016/j.wasman.2015.01.027.

[3] Chen H, Yan SH, Ye ZL, Meng HJ, Zhu YG. Environ Sci Pollut Res. 2012;19:1454-1463. DOI: 10.1007/s11356-012-0760-0.

[4] Kacprzak M, Neczaj E, Fijałkowski K, Grobelak A, Grosser A, Worwąg M, et al. Environ Res. 2017;156:39-46. DOI: 10.1016/j.envres.2017.03.010.

[5] Lewandowski I, Weger J, Hooijdonk A, Havlickowa K, Dam J, Faaij A. Biomass Bioenergy. 2006;30:405-421. DOI: 10.1016/j.biombioe.2005.11.020.

[6] Kołodziej B, Stachyra M, Antonkiewicz J, Bielińska E, Wiśniewski J. Biomass Bioenergy. 2016;85:363-370. DOI: 10.1016/j.biombioe.2015.12.025.

[7] Chen Y, Yu F, Liang S, Wang Z, Liu Z, Xiong Y. Waste Manage. 2014;34:2014-2021. DOI: 10.1016/j.wasman.2014.06.029.

[8] Wang JY, Zhang DS, Stabnikova O, Tay JH. J Hazard Mater. 2005;B124:139-146. DOI: 10.1016/j.jhazmat.2005.04.036.

[9] Antonkiewicz J, Kołodziej B, Bielińska EJ, Gleń-Karolczyk K. J Elem. 2019;24(3):987-1005. DOI: 10.5601/jelem.2018.23.4.1757.

[10] Kidd P, Mench M, Álvarez-López V, Bert V, Dimitriou I, Friesl-Hanl W, et al. Int J Phytoremediation. 2015;17:1005-1037. DOI: 10.1080/15226514.2014.1003788.

[11] Magdziarz A, Wilk M. J Therm Anal Calorim. 2013;114:519-529. DOI: 10.1007/s10973-012-2933-y.

[12] Werle S. Ecol Chem Eng S. 2015;22:459-469. DOI: 10.1515/eces-2015-0027.

[13] Gondek K, Kopeć M, Mierzwa M, Tabak M, Chmiel M. J Elementol. 2014;19:377-390. DOI: 10.5601/jelem.2014.19.2.670. 
[14] Krzywy-Gawrońska E. Ecol Chem Eng S. 2013;20(2):303-320. DOI: 10.2478/eces-2013-0022.

[15] Regulation of the Minister of the Environment on municipal sewage sludge dated 6 February 2015. J Laws of Poland, Item 257; 2015. http://isap.sejm.gov.pl/DetailsServlet?id=WDU20150000257.

[16] Grobelak A, Grosser A, Kacprzak M, Kamizela T. J Environ Manage. 2019:234:90-96. DOI: 10.1016/j.jenvman.2018.12.111

[17] Kicińska A, Gucwa J, Kosa-Burda B. Bull Environ Contam Toxicol. 2019;102(3):399-406. DOI: 10.1007/s00128-018-2517-z.

[18] Deeks LK, Chaney K, Murray C, Sakrabani R, Gedara S, Le MS, et al. Agron Sustain Dev. 2013;33:539-549. DOI: 10.1007/s13593-013-0135-z.

[19] Haynes RJ, Naidu R. Nutr Cycling Agroecosyst. 1998;51:123-137. DOI: 10.1023/A:1009738307837.

[20] Kapanen A, Vikman M, Rajasärkkä J, Mirta M, Itävaara M. Waste Manage. 2013;33:1451-1460. DOI: 10.1016/j.wasman.2013.02.022.

[21] Systematyka gleb Polski (Polish Soil Classification). Soil Sci. Annu. 2011;62(3):1-193. http://ssa.ptg.sggw.pl/issues/2011/623.

[22] Stanek-Tarkowska J, Czyż EA, Dexter AR, Sławiński C. Int Agrophys. 2018;32(3):403-409. DOI: 10.1515/intag-2017-0016.

[23] Regulation 2015. Regulation of the Minister of the Environment on the R10 recovery process dated 20 January 2015. J Laws of Poland, Item 132. http://isap.sejm.gov.pl/DetailsServlet?id=WDU20150000132.

[24] Regulation of the Minister of the Environment on how to conduct land surface pollution assessment dated 1 September 2016. J Laws of Poland, Item 1395; 2016. http://isap.sejm.gov.pl/ DetailsServlet?id=WDU20160001395.

[25] Waste Catalogue. Regulation of the Minister of the Environment on catalog of wastes dated 9 December 2014. J Laws of Poland, Item 1923; 2014. http://isap.sejm.gov.pl/DetailsServlet?id=WDU20140001923.

[26] Gondek K. J Elementol. 2012;17:231-245. DOI: 10.5601/jelem.2012.17.2.06.

[27] Ostrowska A, Gawliński S, Szczubiałka Z. Metody analizy i oceny właściwości gleb i roślin. Katalog. (Methods of analysis and assessment of soil and plant properties. A Catalgoue.) Warszawa: Institute of Environmental Protection - National Research Institute; 1991.

[28] Jones JB. Jr, Case VV. Sampling, handling, and analyzing plant tissue samples. Chapter 15. In: Westerman RL, editor. Soil Testing and Plant Analysis. Madison, WI: Soil Science Society of America, Inc. 1990.

[29] Lošák T, Hlušek J, Lampartom I, Elbl J, Mühlbachová G, Čermák P, et al. Acta Univ Agric Silvic Mendelianae Brun. 2016;64:1603-1608. DOI: 10.11118/actaun201664051603.

[30] Cukjati N, Zupančič GD, Roš M, Grilc V. J Environ Manage. 2012;106:48-55. DOI: 10.1016/j.jenvman.2012.04.001.

[31] Boumaleka W, Kettaba A, Bensaciab N, Bruzzonitic MC, Othmand DB, Mandie L, et al. Desalin Water Treat. 2019;143:178-183. DOI: 10.5004/dwt.2019.23559.

[32] Guedes P, Couto N, Ottosen LM, Kirkelund GM, Mateus E, Ribeiro AB. Waste Manage. 2016;52:193-201. DOI: 10.1016/j.wasman.2016.03.040.

[33] Huang S, Huang H, Zhu H. Environ Sci Pollut Res. 2016;23:10022-10027. DOI: 10.1007/s11356-016-6188-1.

[34] Wooding AR, Kavale S, MacRitchie F, Stoddard FL, Wallace A. Cereal Chem. 2000;77:798-807. DOI: 10.1094/CCHEM.2000.77.6.798.

[35] Johansson E, Prieto-Linde ML, Jönsson JÖ. Cereal Chem. 2001;78:19-25. DOI: 10.1094/CCHEM.2001.78.1.1.9.

[36] Mayer J, Gunst L, Mäder P, Samson MF, Carcea M, Narducci V, et al. Eur J Agron. 2015;65:27-39. DOI: 10.1016/j.eja.2015.01.002.

[37] Hamnér K, Weih M, Eriksson J, Kirchmann H. Field Crops Res. 2017;213:118-129. DOI: 10.1016/j.fcr.2017.08.002.

[38] Matraszek R. Hawrylak-Nowak B, Chwil S, Chwil M. Environ Sci Pollut Res. 2016;23:5902-5914. DOI: 10.1007/s11356-015-5823-6.

[39] Doltra J, Lægdsmand M, Olesen JE. Eur J Agron. 2011;34:83-95. DOI: 10.1016/j.eja.2010.11.002.

[40] Obernberger I, Brenner T, Bärnthaler G. Biomass Bioenergy. 2006;30:73-982. DOI: 10.1016/j.biombioe.2006.06.011.

[41] Gilbert P, Thornley P, Riche AB. Biomass Bioenergy. 2011;35:1170-1181. DOI: 10.1016/j.biombioe.2010.12.002.

[42] Mackowiak CL, Myer RO, Blount AR, Foster JL, Barnett RD. J Plant Nutr. 2011;34:1828-1842. DOI: 10.1080/01904167.2011.600410.

[43] Plank CO, Donohue SJ. Small grain (barley, oats, rye, wheat). In: Campbell CR, editor. Reference Sufficiency Ranges for Plant Analysis in the Southern Region of the United States. Southern Cooperative Series Bulletin, 394, 2000. ISBN 1581613946. www.ncagr.gov/agronomi/saaesd/scsb394.pdf. 
[44] Debiase G, Montemurro F, Fiore A, Rotolo C, Farrag K, Miccolis A, et al. Eur J Agron. 2016;75:149-157. DOI: 10.1016/j.eja.2015.12.009.

[45] Petersen SO, Henriksen K, Mortensen GK, Krogh PH, Brandt KK, Sørensen J, et al. Soil Tillage Res. 2003;72:139-152. DOI: 10.1016/S0167-1987(03)00084-9.

[46] Ruisi P, Saia S, Badagliacca G, Amato G, Frenda AS, Giambalvo D, et al. Field Crops Res. 2016;189:51-58. DOI: 10.1016/j.fcr.2016.02.009.

[47] Antonkiewicz J. J Elementol. 2010;15:435-443. DOI: 10.5601/jelem.2010.15.3.435-443

[48] Puls R. Mineral Levels in Animal Health. Diagnostic Data. Clearbrook, BC: Sherpa International; 1994. ISBN 0969342926.

[49] Poutanen K, Sozer N, Valle GD. J Cereal Sci. 2014; 59:327-336. DOI: 10.1016/j.jcs.2014.01.009.

[50] Tonn B, Thumm U, Lewandowski I, Claupein W. Biomass Bioenergy. 2012;36:390-403. DOI: 10.1016/j.biombioe.2011.11.014. 